Article

\title{
Negotiating Space and Visibility: Forms of Informality in Public Space
}

\author{
Hesam Kamalipour $1, *\left(\mathbb{D}\right.$ and Nastaran Peimani ${ }^{2}$ (D) \\ 1 School of Geography and Planning, Cardiff University, Cardiff CF10 3WA, UK \\ 2 Welsh School of Architecture, Cardiff University, Cardiff CF10 3NB, UK \\ * Correspondence: kamalipourh@cardiff.ac.uk; Tel.: +44-292-087-74463
}

Received: 30 June 2019; Accepted: 28 August 2019; Published: 3 September 2019

check for updates

\begin{abstract}
Street trading has become integral to how public space works in cities of the global South. It cannot be considered as marginal since it gears to the urban economy and works as a key mode of income generation for the urban poor to sustain livelihoods. A poor understanding of how forms of street trading work in public space can lead to poor design and policy interventions. While many practices of formalization aim at the elimination of informality, the challenge is to explore the complex informal/formal relations and the dynamics of street trading to understand how forms of informality negotiate space and visibility in the public realm. In this paper, we propose a typology of street trading, based on the criteria of mobility within public space and proximity to public/private urban interfaces. While exploring the degrees of mobility in informal street trading can be crucial to the modes of governance and adaptability involved, of critical importance is to investigate how street trading takes place in relation to the built form-particularly the edges of public space where public/private interfaces enable or constrain exchange and appropriation. The developed typology provides a better understanding of the dynamics of street trading and contributes to the ways in which the built environment professions can most effectively engage with interventions in public space without eradicating the scope for informal adaptations.
\end{abstract}

Keywords: informality; informal trading; typology; public open space; tactical urbanism; street vending; public/private interface; street trading; informal urbanism; appropriation; public space; urbanism

\section{Introduction}

Cities have become the primary centers of opportunities and jobs, accommodating more than half of the global population [1]. Cities of the global South have been increasingly facing the consequences of globalization and international restructuring of the global economy. They have become exposed to the effects of global accumulation of capital to which local trade has to adapt for economic survival. We can link informal urbanism to macro-scale economic and geopolitical dynamics, but forms of informality are not necessarily consequences or problems of capitalism [2]. As a self- or collectively-organized activity with relatively high levels of adaptability, street trading has become integral to how cities of the global South work. Moving towards a sophisticated understanding of the dynamics of informal urbanism is related to the Sustainable Development Goal 11 (making inclusive and resilient cities), which is by and large the most relevant to the New Urban Agenda adopted at the Habitat III conference. Addressing street trading can also be linked to the other Sustainable Development Goals (SDGs), including SDG 1 (ending poverty), SDG 5 (achieving gender equality), SDG 8 (promoting sustained employment), and SDG 10 (reducing inequality). Street trading can be defined in relation to both legality and location as it generally takes place in publicly accessible urban spaces and at least partially outside the regulatory order [3] (p. 668). Although informal trading has a significant contribution to the 
urban economy, it is often seen by the authorities as marginal [4-7], out of order [8-10] and damaging to the formal market [11]. Challenging the tolerance of the state, itinerant street traders "learn the rules of the game, shifting between a number of interstices in state surveillance and control" [12] (p. 1039). Middle- and low-income urban dwellers often benefit from the products provided by street traders because they are often cheaper, more diverse in range, and more accessible in terms of time and distance than those in the formal market [13]. Therefore, their entrepreneurial activities have the potential to fill the gaps in the formal market and adapt promptly to changing demands. While authorities consider street trading as harmful to the "image" of the city, it has the capacity to add vitality to the streetscapes and stimulate random face-to-face encounters that may otherwise not appear [5]. A sophisticated understanding of how street trading works in public space is then critical for intervention in the built environment. This paper does not evaluate specific formalization projects or prescribe solutions. The aim is to explore the dynamics of street trading and the ways in which street traders negotiate their visibility and spatial claims to sustain livelihoods. Our attempt here is to avoid romanticizing such self-help activities or falling into either optimistic or pessimistic views on urban informality, but rather to explore how forms of informality work in a global context [14,15].

Street trading is a form of urban informality, which can be traced back to the conception of "informal sector" coined by Keith Hart in the 1970s [16] to elaborate on informal/formal income opportunities. De Soto [17] later puts forward the idea of the informal sector as a system operating outside state control, arguing that those involved in informal sector activities "live within a grey area which has a long frontier with the legal world and in which individuals take refuge when the cost of obeying the law outweighs the benefit" [17] (p. 12). Pratt [18] (p. 38) outlines two different economic views on the conceptualization of informality: A structuralist approach argues that the informal sector is forced out of the formal sector to provide cheap labor while the other view considers the informal market as a "response to bureaucratic obstacles" [17] and a failure of formal codes [19]. Although there is a degree of truth in both views, informal/formal processes co-exist in a way that the informal/formal can be considered as a twofold concept rather than a dichotomy [20-22]. While there has been sustained debate over the conception of informality, there remains a good deal of confusion about how such complex and multidimensional concept can be defined and where a clear-cut line can be drawn between formality and informality-if at all. Urban informality can be broadly defined as the activities take place outside formal systems of regulation and state control $[23,24]$, yet it is often tolerated as a safety valve to prevent insurrection [25]. It is also critical to understand that the boundaries between formal and informal are loosely defined [26,27]. Discourse on urban informality and informal trading has focused largely on the distinctions between formal and informal, where one tends to erase and undermine the other. In this paper, we seek to move beyond such binary thinking, drawing on what has been described as a "post-dualist" approach [28], to investigate the dynamic of street trading in public space.

\section{Informal Trading in Public Space}

Questions of urban informality are infused with questions of right over public space-more particularly the capacity to circumvent regulations and transgress the formal codes of the city. This also lends itself to the demarcation proposed by de Certeau [29] between tactics and strategies. Such a distinction can unravel the ways organized strategies of the state confront the self-organized tactics of citizens-what Bayat [30] termed "the quiet encroachment of the ordinary" - particularly in many cities of the global South where urban informality is integral to the everyday life of cities [31], filling the gaps of the formal city and producing a range of urban morphologies [32-35]. Lynch [36] (pp. 205-207) identifies different forms of spatial rights associated with the degree of spatial control: Presence, use and action, appropriation, and modification. The rights to action and appropriation are seen as seminal to the emergence of intensive street life and productive urbanity since they are often concerned with socio-political freedoms in urban public space [36]. Nevertheless, their contribution to urban intensity is subject to their presence and access in public space. In the rapidly growing cities of the global South, 
this condition is also geared to different forms of state control and surveillance. While various practices of spatial control may have overlaps with each other, we are particularly interested in exploring how public space becomes a terrain of negotiation and contestation among different types of street trading.

A street trader is broadly defined as someone offering goods, wares, or food services to the public without occupying a permanent built-up structure [37]. The ways in which street traders choose their locations are reliant on a mix of issues, but most importantly, on pedestrian flows [38] (p. 9), which are in turn mediated by urban attractions. In general terms, street trading is clustered close to prime locations, such as busy intersections and entrances of shopping centers and stations-geared to both urban morphology and functional mix.

Street traders often negotiate their use and appropriation of public space with each other, shopkeepers, motorcycle taxis, and state entities, among others [11,39]. Their goods and vehicles dominate both sidewalks and roads, pushing the boundaries of urban codes and regulations. The capacity of street traders to offer services in self-organized and creative ways relies on their presence in public space, their visibility in relation to pedestrian flows, and the extent to which their use and appropriation are tolerated by the state. Street traders are attracted to pedestrian flows along sidewalks, and their concentration can generate more flows. This might escalate until it results in serious problems such as overcrowding and obstructing traffic flows-what is called the process of "hyper-agglomeration" [5] (p. 15). Shopkeepers are often successful in convincing the municipal officials and state authorities that evicting informal traders from sidewalks will remove unfair competition [40], ease gridlocks and encroachments, and keep public spaces "clean" [13]. Nonetheless, street trading benefits from keeping pedestrian traffic open-severe competition and gridlock become a disincentive to informal trading [11,41].

Permission to trade in public space is usually negotiated with municipal authorities, police officers, adjacent shopkeepers, and local gangs in the form of bribes or a certain share of their income as "unofficial rents" $[9,42,43]$. Paying bribes enables informal businesses to persist, the blind eye to be turned by the state and the powerful. While the threat of heavy fines and even forced eviction through "street cleansing" operations acts as deterrents for street traders, it has been pointed out that they select their locations according to the micro-scale design of public space-such as "the availability of a flat surface for a table or mat; the capacity to wheel a trolley or hang some goods on a wall" [20] (p. 237). Issues such as climatic conditions, flooding, drainage, and danger might be also salient.

Street trading is a gendered form of activity in public space across many cities of the global South $[11,13,39,44]$. It has been argued that female traders in Latin American cities have fewer possibilities to set up the contacts required for their thriving market due to the gendered constraints on their mobility [40]. Bromley [45] argues that male traders in Cali are more involved in large-scale operations (e.g., selling non-food goods), while females are more involved in small-scale operations (e.g., selling food). A recent study of Indian cities [13] shows that female traders are mostly engaged in stationary vending, particularly in proximity to their home where they are accompanied by other female traders. It has been argued that in cities with large Muslim populations, mobile patterns of trading among women are often limited to the female-dominated urban spaces such as women-only train carriages [11]. The static, as well as limited mobile, uses of space by women traders are linked to the problems of vulnerability, intimidation, and insecurity posed by authorities, other male traders, passers-by, and customers [13].

\subsection{Formalization}

The ways street trading is viewed and formalized vary markedly across different cities of the global South as authorities struggle over questions of elimination, tolerance, or regulation. In many cities, according to Bayat [30], state authorities attempt to wage a protracted war against street traders (p. 54); to enforce policies to eliminate them from public spaces, and to place them in state-controlled markets or marginal places. This links to the ways in which street traders are viewed as "out of place" within "modern" cities [10] where their eviction is often justified under the guise of a "global city" 
image [8,27,46], democratization of public space [6] (p. 345), urban aesthetics and public health [47,48], safety and control of economic activities [49]. It has been argued that the inclination of the state to eliminate street traders is driven by desires to tax the informal market, ease traffic congestion, control quality and legality of products, stop the privatization of public space, prevent unfair competition with formal retailers, and cleanse the image of the city [20].

A tolerant approach towards street traders recognizes their enduring presence and contribution in alleviating urban poverty and unemployment $[28,50]$. However, tolerance also preserves the discretionary power of street-level bureaucrats and government officials. The activities of street traders are confined within certain bounds-defined through negotiations between traders and authorities [12,51]. Such temporary agreements have not often lasted long since there has been a lack of explicit regulations in favor of street trading [28]. Some street traders may also become involved in policing public space, which often results in marginalizing those with limited access to resources [39]. What happens is continuous negotiation, and in this way, local officials uphold their informal interests, often via corrupt practices [12]. This raises the question of whether beyond this tolerant approach, there is potential for a more responsive policy approach towards informal trading [28].

Attempts at eviction and relocation have often failed due to the limited capacity of relocation areas in attracting customers [8,52]. This lends itself well to the argument that "when customers fail to follow, the vendors have little choice but to return to the streets" [5] (p. 19). Indeed, the problems of street vendors in the city reflect a conflict between the official expectation of the ideal urban environment and the street vendors as the reality of urban life [10] (pp. 397-398). Nonetheless, the self-organized tactics of everyday life cannot be simply controlled from the top-down. Such enforcement of rigid official regulations in the absence of a sophisticated understanding of the ways formal and informal economies co-function produces a large gap between these two systems. It is then critical to explore how different forms of street trading work before jumping into any conclusion about the ways in which the built environment professions can most effectively engage with practices of formalization.

\subsection{Types}

Early attempts at identifying street trading types consider flexibility and mobility as one of the key characteristics [10,45]. Drawing on evidence from Indonesian cities, Yatmo [10] (pp. 388-390) identified six types of street trading and made two critical distinctions. The first distinction is between the more permanent structures such as informal kiosks and the more temporary claims on public space using mats or tents. The second distinction is between these stationary claims on particular territory and ambulatory trading using pushcarts, baskets, or yokes. Other ambulatory types, including ones using motorcycles, tricycles, or bicycles, have also been identified by Rukmana [9] (p. 140). Similar typologies based on mobility have been proposed by Saha [13] and Bhowmik [37].

Maneepong and Walsh [42] categorize street traders into two groups of old and new generations, pointing to the emergence of "a new generation of street vendors" who operate within the informal network with a better understanding of market shifts. They contrast this group of traders with advanced business, technology, and language skills to the "old generation of street vendors" who often deliver foodservice and low-priced clothing using limited technical skills. This is linked to how the new generation can easily adapt to regulations and rules. The selected location has also been another element of contrast between the two groups. The new generation of traders often offers service in private market areas (i.e., within strategic areas in CBD or tourist areas) while the old generation of traders mostly set up their business in proximity to busy public spaces.

There have been attempts to position street trading in relation to urban morphology and context. Polakit and Boontharm [7], for instance, describe the ways mobile trading in Bangkok is geared to different modes of transport and street hierarchy. The possibility to trade increases where the neighborhood becomes a labyrinth of lanes and alleyways with a variety of canal vendors, hawkers, pushcarts, and bicycle/motorcycle/tricycle vendors. Dense inner urban blocks with limited public transport connectivity and less official control over the use of public space are often seen as places 
where mobile street traders play a crucial role in offering daily goods and services at inhabitants' doors. The use of pushcarts is banned for mobile traders along the main streets and congested lanes. Here, the hawkers on foot are often attracted to pedestrian traffic at major intersections where they skillfully adapt to the rhythms of the traffic lights [7].

Drawing on Bromley [5] and Yatmo [10], Dovey [20] developed an urban spatial typology ranging from a trader using a fixed kiosk, fixed wall/fence, semi-mobile table and mat to a mobile trader with a vehicle or pushcart. This continuum derives initially from the notion of "proxemics" introduced by Hall [53] where public space is construed as an assemblage of walls and buildings (fixed), loose parts (semi-fixed), and people (unfixed). This typology can help demonstrate the extent to which informal trading is fixed as well as adaptable to urban terrain. Each type is differently geared to micro-spatial urban morphology, which is also linked to the extent to which it can be tolerated by city authorities- "the more fixed types are more likely to be tolerated in relatively informal parts of the city while the more mobile vendors are able to infiltrate the more formal city" [20] (p. 238). It has been argued that the extent to which street trading is integrated to a city corresponds to the levels of informality in that city [54] - a temporary kiosk can change into a more permanent building over time. The discussed typology [20] serves as a departure point for the typology of street trading proposed in this paper.

\section{The Proposed Typology of Street Trading}

Figure 1 shows a new typology of street trading based on the matrix formed by two criteria: Mobility within public space and proximity to public/private interface. Mobility-the capacity of a street trader to move within public space-is at the core of earlier typologies. Here, it is based on the same continuum of distinctions made between fixed, semi-fixed, and unfixed trading. The second criterion is the key contribution here. The public/private interface or the edge of public space has long been established as crucial to the social and economic functions of public space, embodied in urban design principles such as the "active edge" [55], "edge effect" [56], "activity pockets" [57], and "eyes on the street" [58]. Under conditions of high pedestrian flow, the interface also becomes a retail opportunity, a potential or actual shopfront. This typology makes a distinction between whether street traders position themselves on the edge of public space or detached from it. In other words, do they become part of the edge of public space or are they "in" public space? The key criterion here, as shown in the diagram, is the question of whether pedestrian traffic can flow between the trader and the interface. This typology incorporates six different conditions that we will illustrate and discuss in turn.
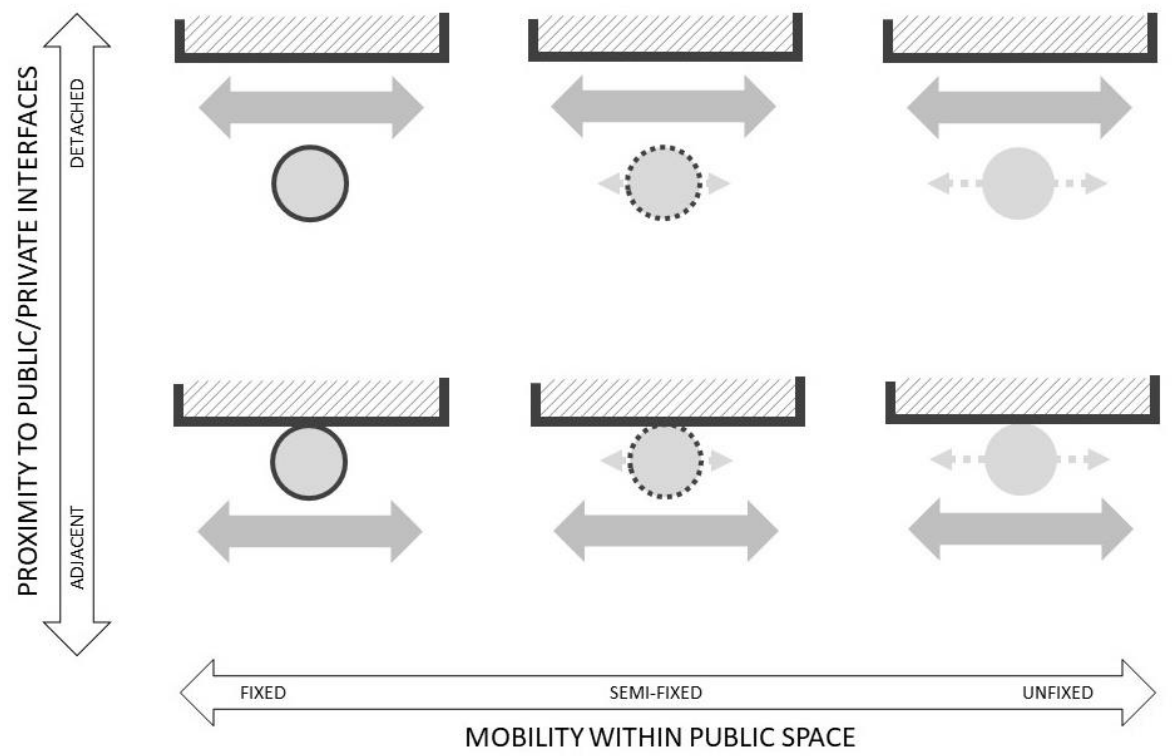

Figure 1. A typology of street trading. Source: Authors. 


\subsection{Detached/Unfixed}

This type refers to a condition where street trading takes place detached from public/private interface with a high capacity to move within public space. As shown in Figure 2, this type is highly adaptable to the rhythms of pedestrian flows as it can quickly move around and become more visible to potential customers. Hence, it is quite competitive in the temporal appropriation of public space and negotiating visibility to the public gaze. The high level of mobility provides the possibility of appropriating different parts of public space; it can also penetrate areas that are not accessible by other types, such as the interiors of public transport services. The range and volume of products are of course, quite limited.

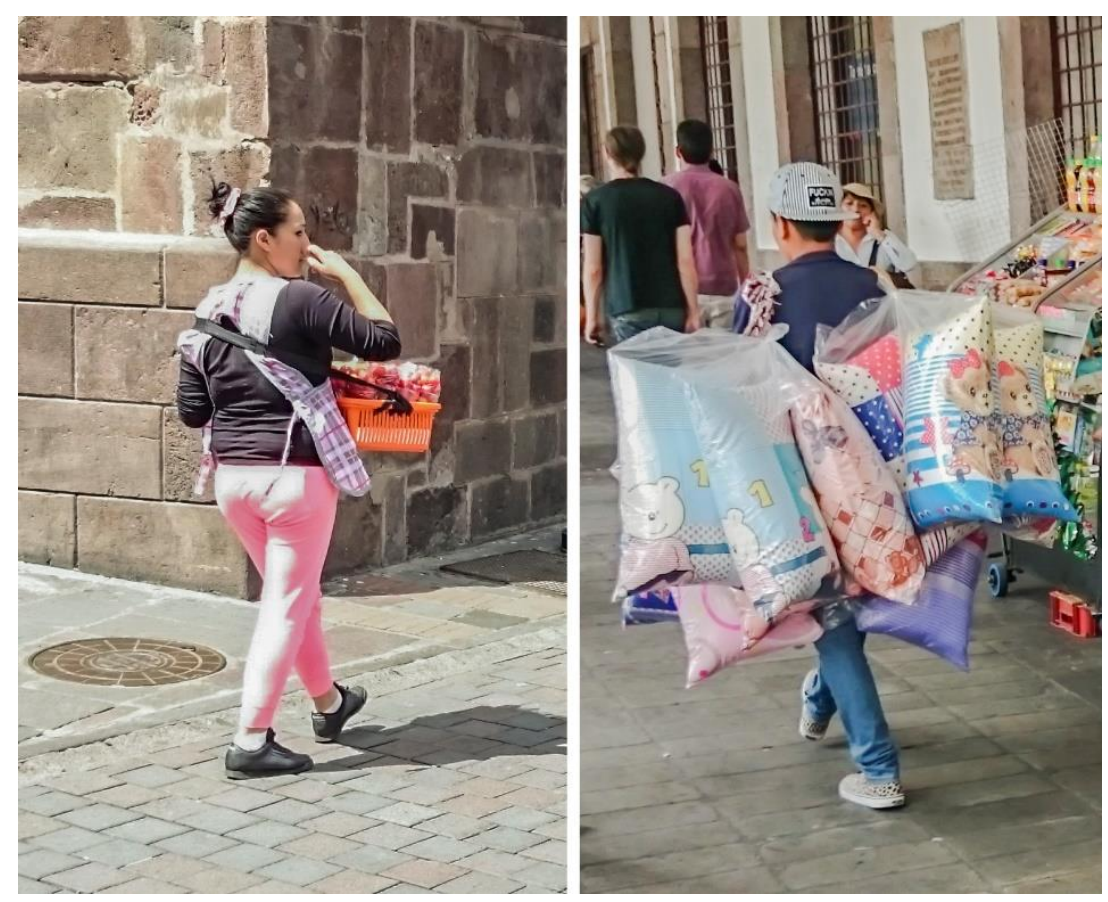

Figure 2. Detached/Unfixed type of street trading in Quito, Ecuador. Photos: Hesam Kamalipour.

\subsection{Detached/Semi-Fixed}

This type refers to a condition where street trading is detached from the edges of public space, yet not quite capable of moving within public space. As shown in Figure 3, the variety and number of products offered by this type often limit its capacity to quickly move within public space. Trolleys are often used in different sizes to allow for both a degree of movement and becoming temporarily fixed in certain parts of public space where found appropriate in relation to pedestrian flows (Figure 3). The capacity of this type for negotiating visibility in public space can become limited depending on its overall size and the number of products being offered. This type often occupies the transition area between cars and sidewalks where it competes with parking (Figure 3). The lines we draw between unfixed, semi-fixed, and fixed are somewhat arbitrary, but based on the time it might take to move. Unfixed implies a capacity to move at the speed of an average pedestrian. Trolleys, pushcarts, umbrellas, tables, or mats are all defined as semi-fixed. Anything that requires a demounting period of more than a few minutes is defined as fixed. 


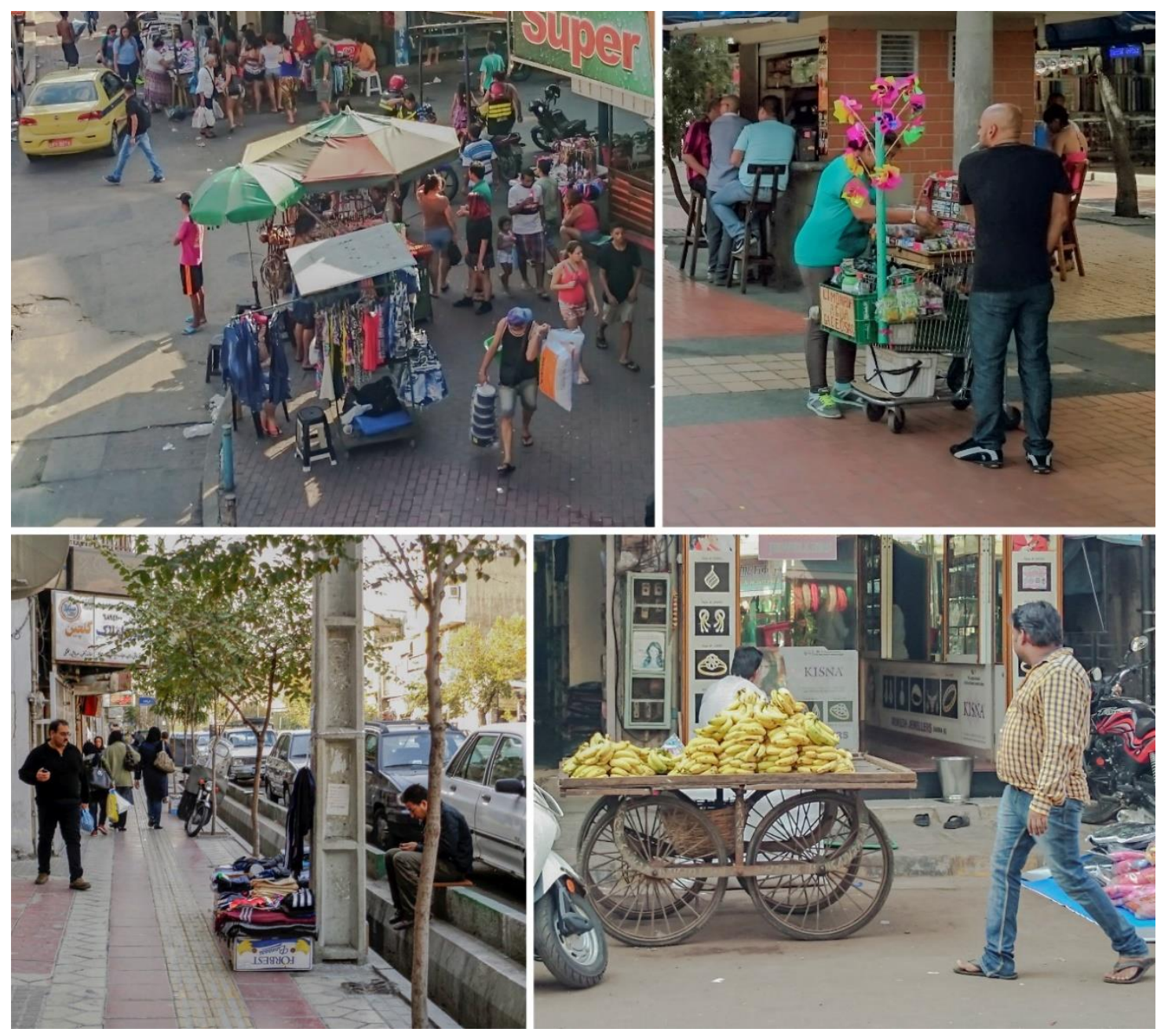

Figure 3. Detached/Semi-fixed type of street trading in Rio de Janeiro, Brazil (upper Left), Medellin, Colombia (upper right), Tehran, Iran (lower left), and Mumbai, India (lower right). Photos: Hesam Kamalipour (upper photos and lower right), Nastaran Peimani (lower left).

\subsection{Detached/Fixed}

This type refers to a condition where street trading takes place detached from public/private interface, yet occupies a part of public space over a longer duration (Figure 4). This type often forms a kiosk as it emerges within a quasi-formal box with relatively cheap and makeshift materials that may or may not be authorized by the state. This type cannot move within public space due to the fixity of its structure. It may also indicate a formalized form of street trading (Figure 4). A key advantage of this type is that a range of different products can be offered and stored for an extended period due to its fixity and the fact that it permanently occupies a specific part of public space. Nonetheless, this type is perhaps the least adaptable to the change of situation in public space. Thus, how it is located in relation to rhythms of pedestrian flows becomes critical to its survival and possible thrive over time. 

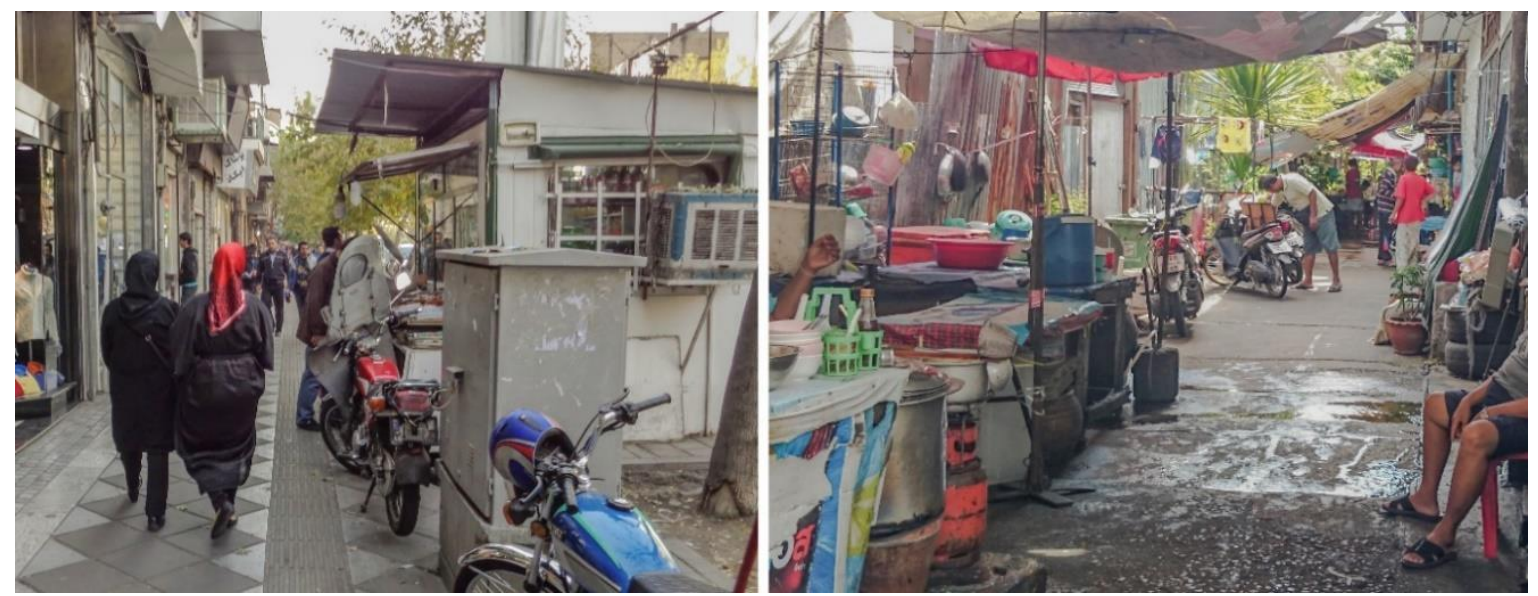

Figure 4. Detached/Fixed type of street trading in Tehran, Iran (left) and Bangkok, Thailand (right).

Photos: Nastaran Peimani (left), Hesam Kamalipour (right).

\subsection{Adjacent/Unfixed}

This type refers to a condition where street trading is attached to the edge of public space, yet capable of possible relocations within public space. As shown in Figure 5, the establishment of this type often relies on the availability of certain types of public/private interface along the edges of public space. Impermeable public/private interfaces, such as blank walls and fences, have the affordance of becoming appropriated by this type of street trading (Figure 5). In this case, such urban interfaces also contribute to the visibility of this type as they provide a visual framing in the form of a blank background. A limited number of products can be temporarily hanged on such edges of public space as the offered products in this type need to be carried by one person (Figure 5). Nonetheless, not all of the impermeable public/private interfaces are likely to be appropriated by this type of street trading because the location is also linked to the proximity to pedestrian flows. A key feature of this type is its capacity to work as a temporary intervention at the micro scale to transform and revitalize those inactive edges of public space that have been produced through formal processes of urban development.
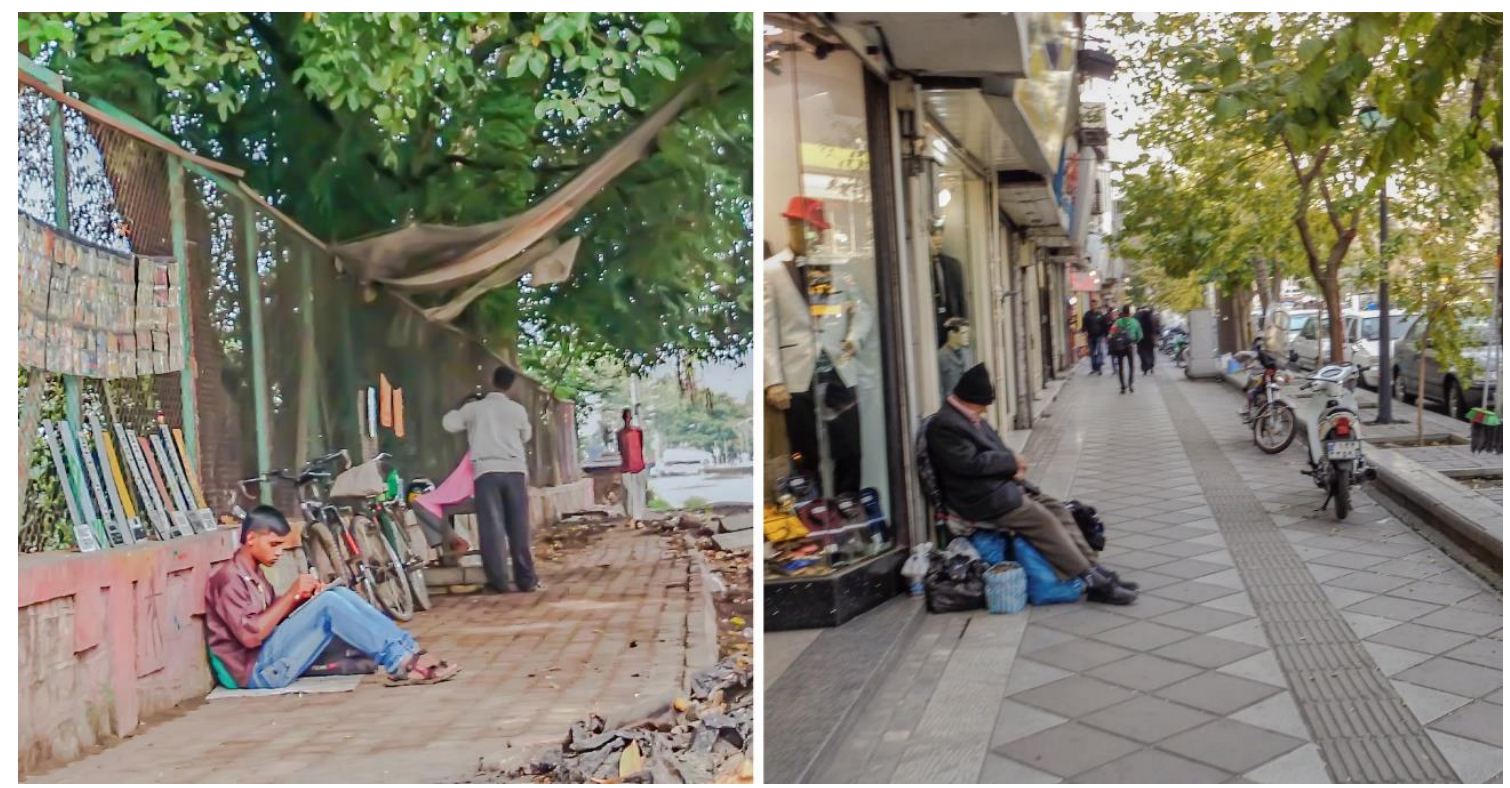

Figure 5. Adjacent/Unfixed type of street trading in Pune, India (left) and Tehran, Iran (right). Photos: Hesam Kamalipour (left), Nastaran Peimani (right). 


\subsection{Adjacent/Semi-Fixed}

This type refers to a condition where street trading is attached to public/private interface, yet not fixed in its current location. As shown in Figure 6, products are often carried around using a fairly small carrier (e.g., pushcart, trolley). This type has the capacity to move within public space in response to the changing pattern of pedestrian flows. However, this capacity is conditional to the number of products and size of the carrier. This type is generally found along the impermeable public/private interfaces where a formal attraction does not exist. Blank walls, fences, and unused entrances along the busy parts of public space are likely to be appropriated by this type of street trading (Figure 6).
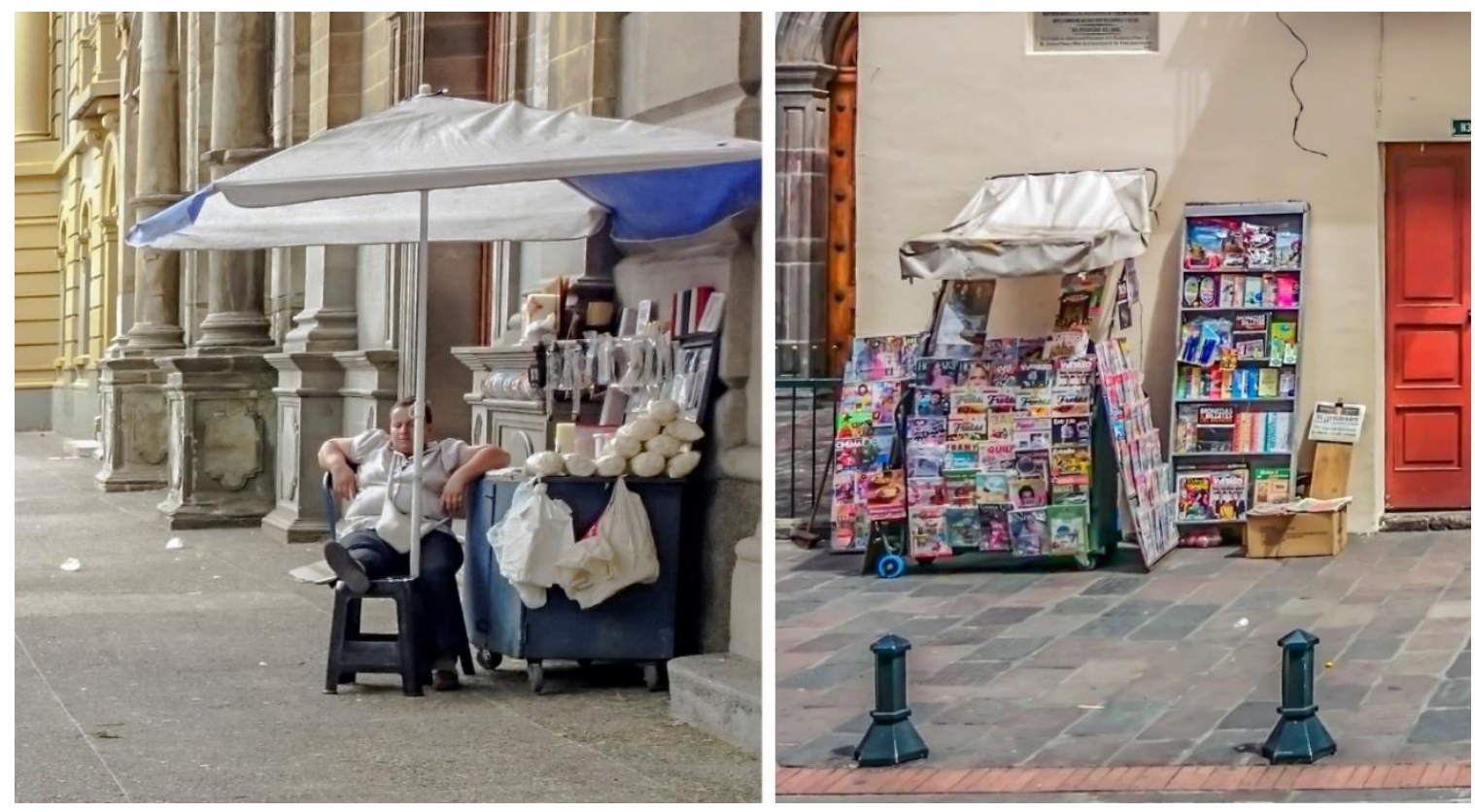

Figure 6. Adjacent/Semi-fixed type of street trading in Medellin, Colombia (left) and Quito, Ecuador (right). Photos: Hesam Kamalipour.

\subsection{Adjacent/Fixed}

This type refers to a condition where street trading is permanently attached to the edges of public space in a fixed location. As shown in Figure 7, the emergence of this type hinges on a pre-existing formal structure. To put it differently, this form of urban informality is likely to emerge and thrive as long as it can be attached to a formal structure as an extension. As this type permanently occupies a part of public space, its location is often negotiated with the adjacent formal structure. The impermeable public/private interfaces are often those parts of a formal structure where street traders of this type are attached to. Access to facilities (e.g., electricity, water) is also negotiated and agreed upon with the owner or renter of adjacent formal structures. This type can informally, yet permanently transform those parts of a formal structure that do not necessarily contribute to the vitality of street life and economic productivity (Figure 7). 

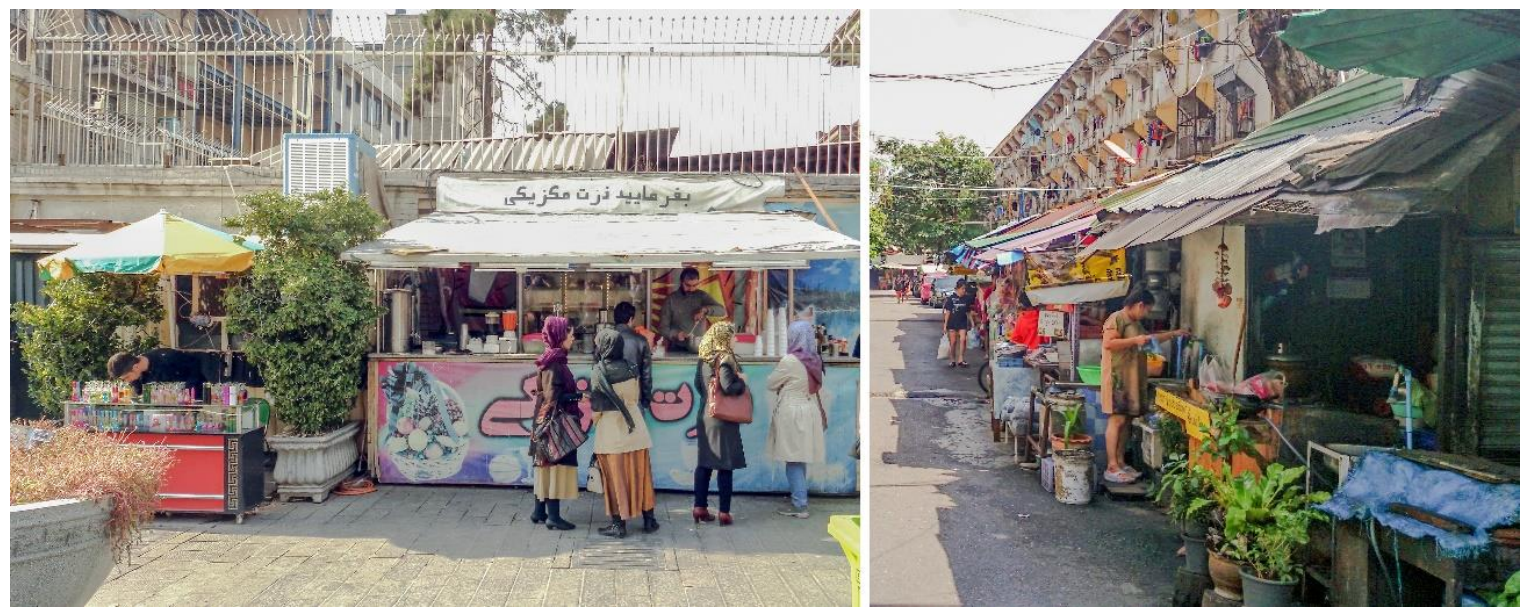

Figure 7. Adjacent/Fixed type of street trading in Tehran, Iran (left) and Bangkok, Thailand (right).

Photos: Nastaran Peimani (left) and Hesam Kamalipour (right).

\section{Synergies and Contradictions}

Thus far, we have introduced the developed typology and described the main characteristics of each type. Nevertheless, as the outlined criteria-proximity to public/private interface and mobility within public space-form continuums, a range of in-between conditions and possibly other types can also be identified. This can, in turn, potentially increase the overlaps between them. There is no claim here for developing a comprehensive typology of street trading as some of the outlined types have not been entirely settled, and there is also possible slippage between them. It is often impossible to draw clear-cut boundaries between the identified types where one type can become another in response to the dynamics of control in public space. These types are neither archetypes nor mutually exclusive as they may also coexist within a public space at the same time (Figure 8). In this section, we focus on the synergies and contradictions between the outlined types of street trading in negotiation for space and visibility.

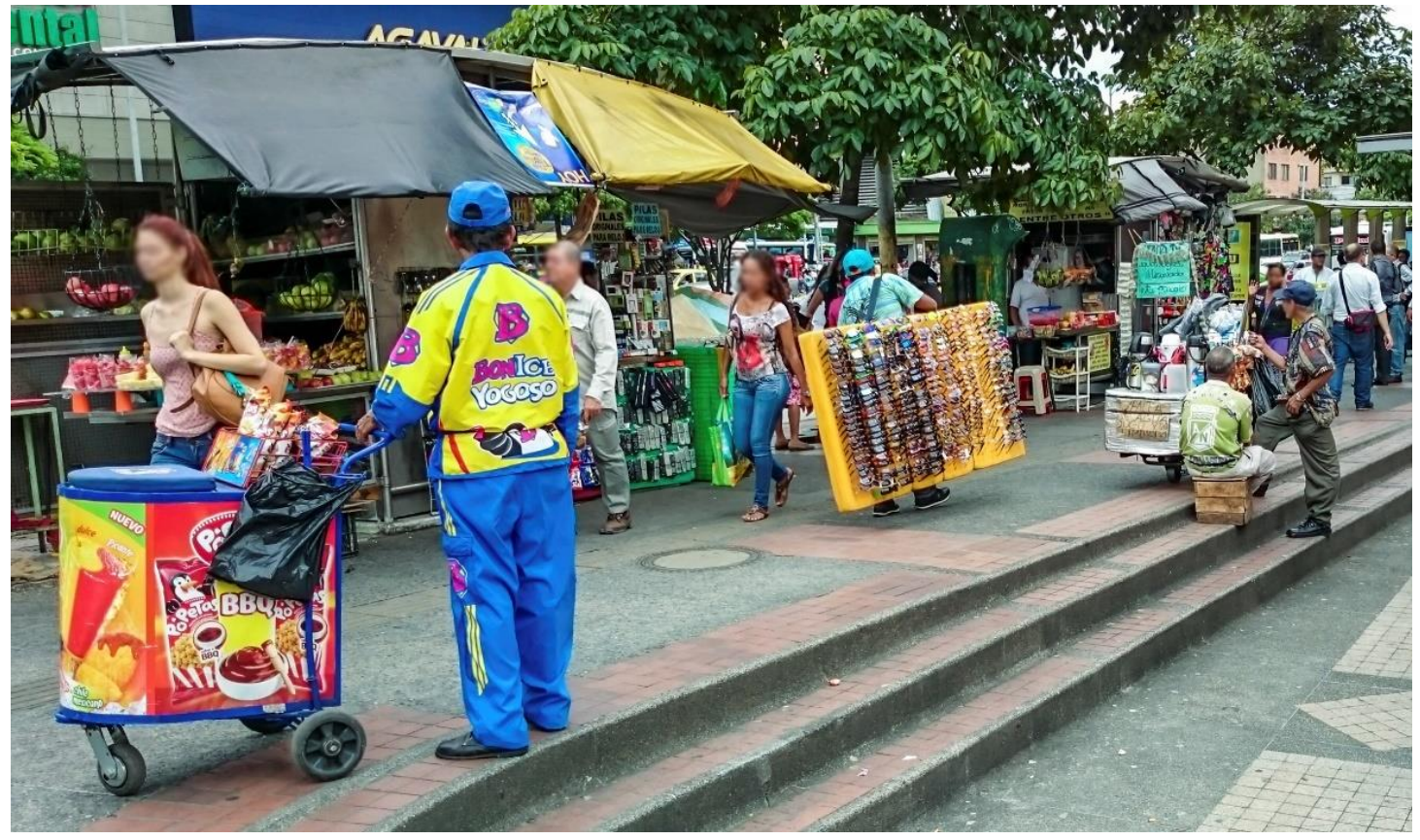

Figure 8. A mix of types with different catchment areas. Different types of street trading that co-exist within public space in Medellin, Colombia. Photo: Hesam Kamalipour. 
The synergies and contradictions are linked to the capacity of different types to attract potential customers by negotiating their visibility and claim for the public space to sustain livelihoods. This capacity varies across the outlined types depending on their "catchment areas"-loose spatial territories surrounding street traders that can potentially catch passers-by. Observations show that the catchment areas often range at once from more temporary (unfixed types) to more permanent (fixed types), and from up to about $1 \mathrm{~m}$ (unfixed types) to up to about $3 \mathrm{~m}$ (semi-fixed types) and ultimately up to about $6 \mathrm{~m}$ (fixed types). While the dynamics of catchment areas are subject to a range of contextual factors, increasing the overlaps between catchment areas and pedestrian flows is perhaps the key to sustain livelihoods as it enables close encounters with the pool of potential customers in public space (Figure 8).

The first distinction in relation to "catchment areas" is between detached and adjacent types. The detached types often incorporate larger catchments areas as they can potentially make use of their surrounding area while the adjacent types are limited in this regard as they are attached, at least from one side, to public/private interface. The second distinction is between fixed, semi-fixed, and unfixed types. The catchment areas of the fixed types are often larger than those of the semi-fixed and unfixed types. The unfixed types then have the smallest catchment areas. While the capacity to move within public space decreases from unfixed to fixed types, the catchment areas increase from unfixed to fixed types (Figure 8). Moving within public space is then a tactic to maintain a continuous encounter with pedestrian flows. The synergy here is about the co-functioning of different types of street trading where the unfixed and semi-fixed types can at once support and benefit from the capacity of the fixed types to attract pockets of activity.

The increasing overlaps between different catchment areas can potentially give rise to conflict and exclusion of the more vulnerable traders. There is a potential for the unfixed and semi-fixed types to reduce the degree of conflict by offering different goods or working as fillers to maneuver between the pockets of activity emerged within the catchment areas of the fixed types (Figure 8). Formal shops also contribute to the emergence of activity pockets in proximity to their interfaces. The common characteristic between formal shops and fixed types is that they both benefit from high visibility in public space and both can potentially attract the same customers on an everyday basis due to the fixity of their location and the goods they offer.

Street trading cannot be assumed as a marginal activity subject to elimination through hostile practices of "urban cleansing" as it gears to urban employment, street life vitality, and how public space works. While temporary appropriations of space serve the private interests of street traders, the collective use of public space can contribute to the public interest by reducing poverty and providing urban services and employment [59] (p. 240). Street trading constitutes a major part of a much broader informal economy by creating job opportunities for the urban poor and low-skilled rural-to-urban migrants in many cities. It also works as a micro-scale design intervention that has the capacity to bring vitality to public space (Figure 9). However, it can challenge the tolerance of the state as it is often considered harmful to the image of an "ordered" city. This leads us to discuss the contradictions of street trading when it comes to the dynamics of image and visibility in public space.

Visibility has a contradictory role in relation to different types of street trading. It can work both for and against the ways in which urban livelihoods can be sustained in public space. It is in the interest of street traders to increase their exposure to the public gaze as their livelihoods rely on attracting more potential customers in public space. However, visibility can stimulate eviction, especially where forms of informality are considered harmful to the image of the state [60]. Hostile attempts can then be justified by the authorities under the guise of a well-ordered city. While street traders compete to increase their exposure in public space for private gain, their visibility has the capacity to transform place identity and challenge the tolerance of the key actors involved in the governance of public space. Certain types of street trading, such as the unfixed types, and to some extent semi-fixed types, have the capacity to negotiate the dynamics of visibility while the fixed types are less adaptable in this regard and more vulnerable to changing circumstances. 

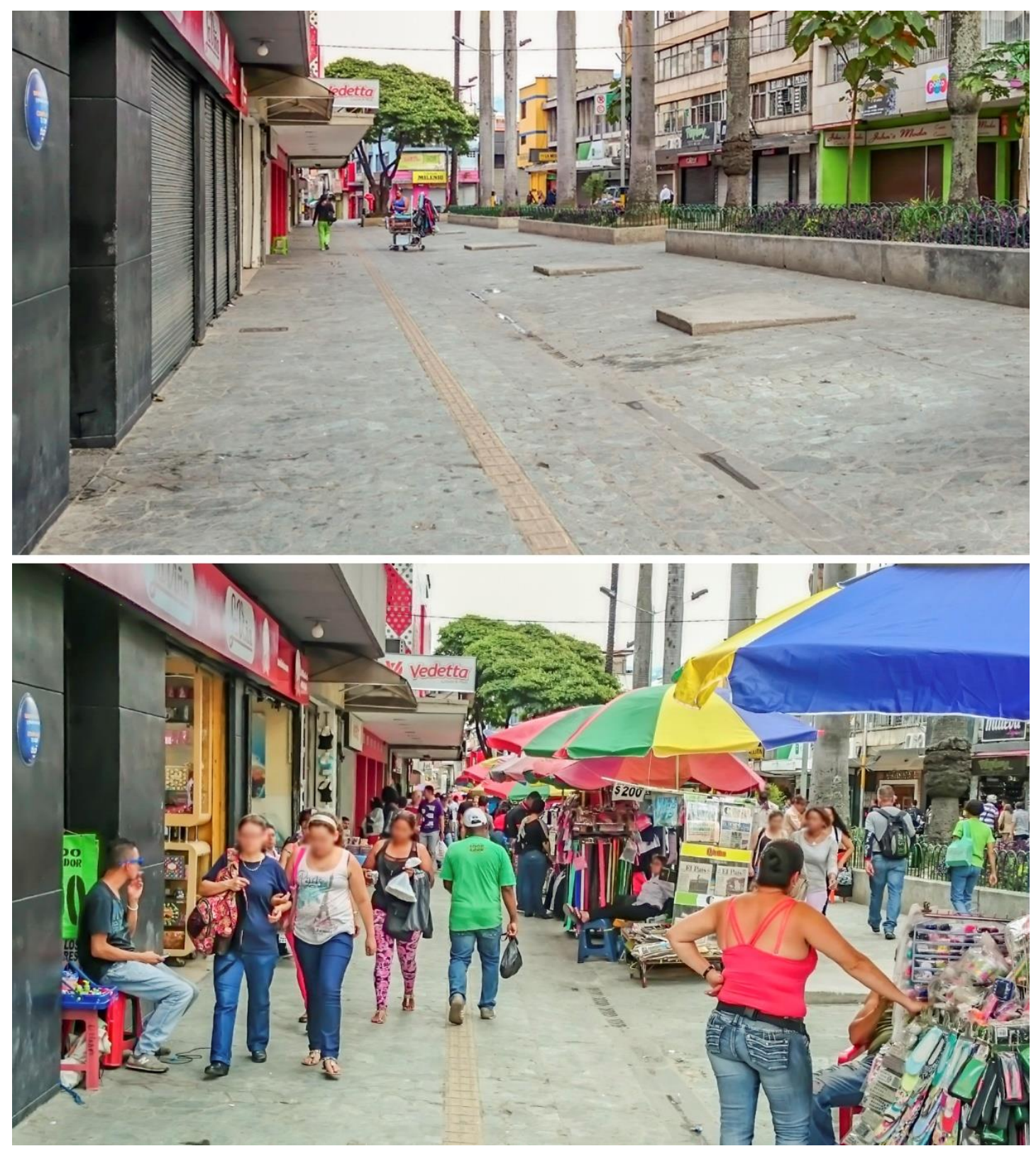

Figure 9. Street trading as a micro-scale design intervention that can bring vitality to public space. Medellin, Columbia. Photos: Hesam Kamalipour.

Street traders negotiate their visibility and use of space not only with each other but also with formal businesses. Land in the public realm is an asset for street traders to manage livelihoods yet is subject to a range of contested claims, which have remained underexplored [59] (p. 239). While street traders and shopkeepers may even collaborate to further materialize their claims over public space, they often play a contradictory role in relation to each other. Street traders generally appropriate those parts of public space with high pedestrian flows. The presence of street traders and their capacity to make use of loose elements (e.g., pushcarts, goods, tables, and food stalls) can contribute to the flexibility of use and attract high volumes of pedestrian traffic. This is a win-win situation for both informal traders and shopkeepers as long as the excessive concentration of activity pockets does not escalate to the blockage of pedestrian flows. It is then critical for both street traders and shopkeepers to keep pedestrian flows open. Excessive appropriation of public space may otherwise produce severe competitions and gridlocks due to which many traders will leave their territories [41]. While both 
street traders and shopkeepers can contribute to the transformation of pedestrian flows to a mix of stationary pockets of activity, at stake is to prevent the emergence of what is known as the "tragedy of the commons" where private interests take over [61]. The key actors-including street traders and shopkeepers, among others-may also collaborate to keep the public realm open and functional. However, such collaborations can become exclusionary as well. The unfixed and semi-fixed types that are detached from the edge of public space are more likely to be displaced through informal practices of control.

There is a complex relationship between different types of street trading and urban morphologies, including functional mix and public/private interface. Forms of informality have the capacity to identify and make use of spatial possibilities through tactical practices of urban transformation. Informality incorporates an adaptive capacity that is often overlooked in many formal urban developments [32]. Shops are among the primary examples of such developments that are generally fixed and permanently located along the edges of public space. Street traders can generate temporary functions that can potentially contribute to the functional mix of the area. At a very small scale, each type of street trading incorporates a mix of work and visit. At a larger scale, street traders can intensify the overall mix of work and visit within a particular area due to their capacity in offering a range of different goods and remaining adaptive to the changing demands and desires of pedestrian flows. The synergy here is about how certain types of street traders can remain market-responsive by offering a range of goods and services, even on the move, where formal shops fall short due to the fixity of their location as well as the type of goods and services they can offer. The unfixed and semi-fixed types are more mobile comparing to the fixed types, which tend to be more permanent in location. The detached unfixed and semi-fixed types can work as moving attractions in public space, contributing to the dynamics of functional mix.

Certain types of street trading can also transform the edges of public space where formal design interventions have failed to address the complexity of public/private relations along the sidewalks. The production of impermeable public/private interface seems to be inevitable in many practices of urban development. While impermeable edges are largely considered as inactive with limited contribution to street life vitality [55,62-65], fixing them through formal design interventions can be quite resource-intensive. The adjacent types of street trading have the capacity to pick up what the built form left off. They can temporarily claim back those impermeable public/private interfaces. The most relevant types here are the ones located adjacent to such edges of public space. The contradiction here is that while adjacent types can activate impermeable interfaces, they can become exclusionary depending on the extent to which they encroach onto the public space (Figure 10). An excessive appropriation of public space by the adjacent types of street traders can constrain inclusive access to the sidewalks. As shown in Figure 10, impermeable interfaces can be transformed in many ways by street traders, shopkeepers, and other formal businesses to enhance their visibility in the public realm by materializing their claims over public space. Nonetheless, such territorial claims are often tolerated or resisted in different ways, depending on whose right to public space is favored.

Policing the public space often works through a mix of contestation, collaboration, and competition between street traders, shopkeepers, and the state [39]. Contestations between them often lead to the displacement of the more fixed types of street trading and the popularity of the semi-fixed type mainly due to its capacity to enable fast packing/unpacking - if needed [39] (p. 182). At stake is the capacity of different types to adapt to changing circumstances. Collaborations between some shopkeepers and street traders may result in sustaining a temporary appropriation of public space by different types. The capacity of street traders-the adjacent types in particular-to benefit the formal market can turn them into the "employees" of the shopkeepers who rent the interface between public space and their shops as well as a part of the public space in proximity to their shops [39] (p. 184). Competitions for public space in the absence of the state control/surveillance can become exclusionary due to the ways in which certain groups of street traders with limited access to resources (e.g., female vendors or individuals who do not work with organized groups of street traders) become simply overlooked 
or disadvantaged in accessing prime locations [39] (p. 186). Exclusionary practices also apply to specific types of street trading. Exploring the prevalence of different types and their positioning in relation to each other in public space is beyond the scope of this paper yet critical to provide a better understanding of how certain types are more likely to be excluded in fierce competitions over public space.
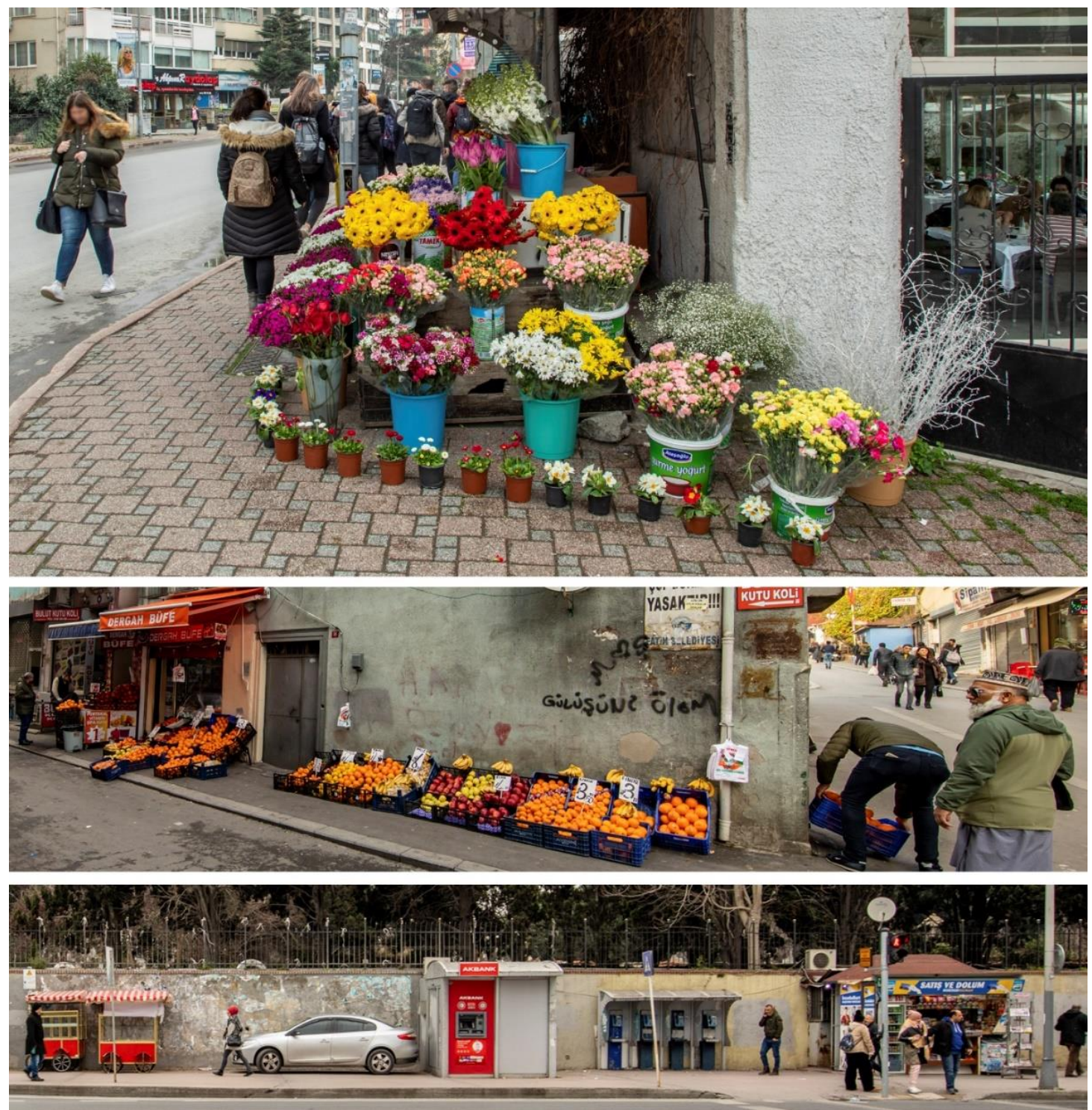

Figure 10. Territorial claims over public space can be tolerated or resisted in different ways depending on whose right to public space is favored. Impermeable interfaces are transformed in many ways by materializing different claims over public space in Istanbul, Turkey. Photos: Hesam Kamalipour.

The predominance of certain types of street trading in public space indicates how collaborative practices between street traders, shopkeepers, and the state functionaries can give rise to a monopoly. This is often the case where semi-fixed or fixed types take over and exclude the more vulnerable groups of traders. While such collaborations can multiply the capacity of certain types to attract potential customers by increasing the overlaps between their catchment areas and pedestrian flows, they can also exclude other types and/or particular groups of street traders. The contradiction here is that exclusion can become a byproduct of collaborative processes. The unfixed types are more likely to become excluded from public space in the monopoly of semi-fixed or fixed types. The marginalized 
individual male and female traders then rely on their capacity to move in order to sustain livelihoods by temporary appropriations of the less prime locations in public space. Mobility here becomes an asset to manage the emerging dynamics of order and exclusion.

\section{Conclusions}

In this paper, we have proposed a typology of street trading based on two criteria-mobility within public space and proximity to public/private urban interface. A matrix of six typical conditions has been developed according to the capacity of street traders to move within public space (unfixed, semi-fixed, or fixed), on the one hand, and how street traders position themselves in relation to the edges of public space (adjacent or detached), on the other. We discussed that the criteria used to develop the outlined types form a continuum and have their roots in the existing literature. The key contribution of the proposed typology is about making a distinction between detached and adjacent types of street trading as mobility has been the primary focus of the earlier typologies. Drawing on various illustrations from a broad range of cities in the global South, we outlined the key characteristics of different types and further discussed the synergies and contradictions between the key actors-including street traders, shopkeepers, and the state functionaries-in negotiating space and visibility. We also made it clear that the proposed matrix is not exhaustive, the identified types are not mutually exclusive, and each type is not an archetype. We pointed out that the micro-scale dynamics of how street traders negotiate and materialize a range of spatial claims have remained underexplored, particularly in relation to the public/private interface or the edges of public space-which has long been established as critical to the social and economic functions of public space.

While there is nothing new about how street traders become attracted to the areas with high levels of pedestrian flows, we argued that their capacity to sustain livelihoods relies, in part, on the extent to which they can negotiate their visibility in public space. Remaining competitive by increasing possible overlaps between their "catchment areas" and pedestrian flows has been considered as crucial in enabling chance encounters with the pool of potential customers. Moving smoothly across public space and offering different goods or services are then among the ways to avoid potential conflicts due to an increasing overlap between different catchment areas. The detached types generally incorporate larger catchment areas. The catchment areas of the fixed types are also often larger than those of the semi-fixed and unfixed types. We argued that emerging conflicts between different types of street traders could lead to the exclusion of the more vulnerable ones unless the unfixed and semi-fixed types offer different goods or work as fillers to maneuver between the pockets of activity emerged within the catchment areas of the fixed types.

We discussed how street trading has the capacity to serve at once private and public interests as it is integral to the ways in which informal economies work. The provision of urban services and employment has been previously outlined as the critical contribution of street trading to the public interest [59] (p. 240). We further pointed to the capacity of street trading to work as a micro-scale design intervention, which can contribute to the vitality of public space by activating the impermeable public/private interfaces, intensifying the functional mix, and generating activity pockets. We argued that the adjacent types of street trading could radically change the impermeable edges of public space through tactical practices of urban transformation. Public space cannot become lively if its edges fail [57] (p. 600). Thus, making a distinction between adjacent and detached types of street trading is particularly important as the adjacent types can potentially activate those edges of public space that fall short in contributing to street life intensity. Nonetheless, we pointed out that the productive capacities of street trading can also become destructive where competitions for space and visibility escalate to an excessive appropriation of public space. Such urban escalations can also become exclusionary even in the absence of the state interventions where informal collaborations tend to overlook the more vulnerable groups of street traders-e.g., women and individual traders who are not affiliated to organized groups [39]. Informal collaborations can also give rise to monopoly and collective privatization of public space. 
We discussed the synergies and contradictions between the outlined types in relation to the micro-scale dynamics of the key actors. It was beyond the scope of this paper to explore the macro-scale dynamics of street trading, but it is critical to note that street traders are often linked to much broader and complex networks of trade at the global scale [66]. It has been pointed out that the dynamics of order in public space are shaped by multiple actors through contestation, competition, and collaboration [39]. Hence, we argued that negotiating space and visibility could not be reduced to conventional dichotomies - between the tactics of the ordinary and strategies of the state, or between shopkeepers and street traders. Our attempt has been to explore how different forms of informality work in a global context. Nevertheless, addressing the dynamics of different social, cultural, economic, political contexts or undertaking an in-depth analysis of a specific case study remains as a limitation of our work and a task for future research.

We also pointed to the contradictory role of visibility since it has the capacity to work both for and against how urban livelihoods can be sustained in public space. While visibility can work for street traders in attracting potential customers, it can challenge the tolerance of the state and stimulate eviction as well. The logic of what we call "anticipatory estimation" plays a significant role here. The capacity to anticipate the dynamics of future interventions and to estimate the tolerance of the key actors-including the state and formal businesses, among others-is critical to how certain types can negotiate their visibility and thrive in public space. The unfixed street traders are the most flexible and adaptive to the changing rhythms of pedestrian flows. They are also less vulnerable to the practices of street cleansing as they can quickly pack and move. Fixed street traders and perhaps many of the semi-fixed traders are then more likely to become easier targets for eviction. While fixity often comes with a more sustained condition of visibility and larger catchment areas for street traders, it can work against them in formal practices of street cleansing.

Before jumping into any conclusion about the ways in which the built environment professions can most effectively engage with practices of formalization and upgrading, it is important to step back and rethink the ways in which we understand how forms of street trading negotiate space and visibility. Street trading is a multiplicity, incorporating different types with a range of capacities. Hence, more nuanced approaches to intervention need to be developed and further tailored to different types of street trading. Public space cannot be simply considered as state land where de facto spatial rights become critical to the livelihoods of the urban poor involved in street trading [59] (p. 240). It is indeed a key asset for street traders to sustain their livelihoods. A sophisticated understanding of how different types of street trading work is then crucial to how the built environment professions can address the dynamics of street trading. The task is to harness the productive capacities of informality without compromising the openness and functionality of public space.

Author Contributions: Conceptualization, H.K. and N.P.; methodology, H.K. and N.P.; writing-original draft preparation, H.K. and N.P.; writing—review and editing, N.P. and H.K.; visualization, H.K. and N.P.; project administration, H.K.

Funding: This research received no external funding.

Acknowledgments: The authors wish to thank Professor Kim Dovey for his insightful critique of an earlier version of this paper, Matthijs van Oostrum for his comments on an initial draft, and Debdulal Saha for his suggestions. The authors also would like to thank the three anonymous reviewers and Academic Editor for their time, incisive critique, and constructive comments.

Conflicts of Interest: The authors declare no conflicts of interest.

\section{References}

1. UN-HABITAT. State of the World's Cities 2008/2009: Harmonious Cities; Earthscan: London, UK, 2008.

2. Dovey, K. Uprooting critical urbanism. City 2011, 15, 347-354. [CrossRef]

3. Brown, A.; Lyons, M.; Dankoco, I. Street Traders and the Emerging Spaces for Urban Voice and Citizenship in African Cities. Urban Stud. 2010, 47, 666-683. [CrossRef]

4. Boonjubun, C. Conflicts over streets: The eviction of Bangkok street vendors. Cities 2017, 70, 22-31. [CrossRef] 
5. Bromley, R. Street vending and public policy: A global review. Int. J. Sociol. Soc. Policy 2000, 20, 1-28. [CrossRef]

6. Hunt, S. Citizenship's Place: The State's Creation of Public Space and Street Vendors' Culture of Informality in Bogotá, Colombia. Environ. Plan. D 2009, 27, 331-351. [CrossRef]

7. Polakit, K.; Boontharm, D. Mobile vendors: Persistence of local culture in the changing global economy of Bangkok. In Local Sustainable Urban Development in a Globalized World; Heberle, L.C., Opp, S.M., Eds.; Urban Planning and Environment; Ashgate Publishing: Farnham, UK, 2012; pp. 175-202.

8. Donovan, M.G. Informal Cities and the Contestation of Public Space: The Case of Bogotá's Street Vendors, 1988-2003. Urban Stud. 2008, 45, 29-51. [CrossRef]

9. Rukmana, D. Street Vendors and Planning in Indonesian Cities. Plan. Theory Pract. 2011, 12, 138-144.

10. Yatmo, Y.A. Street Vendors as ‘Out of Place' Urban Elements. J. Urban Des. 2008, 13, 387-402. [CrossRef]

11. Peimani, N. Transit and Urbanity in Tehran. Ph.D. Thesis, University of Melbourne, Melbourne, Australia, 2017.

12. Turner, S.; Schoenberger, L. Street Vendor Livelihoods and Everyday Politics in Hanoi, Vietnam: The Seeds of a Diverse Economy? Urban Stud. 2012, 49, 1027-1044. [CrossRef]

13. Saha, D. Informal Markets, Livelihood and Politics: Street Vendors in Urban India; Routledge: New York, NY, USA, 2017.

14. Kamalipour, H.; Peimani, N. Towards an Informal Turn in the Built Environment Education: Informality and Urban Design Pedagogy. Sustainability 2019, 11, 4163. [CrossRef]

15. Kamalipour, H. Urban Informalogy: The Morphologies and Incremental Transformations of Informal Settlements. Ph.D. Thesis, University of Melbourne, Melbourne, Australia, 2017.

16. Hart, K. Informal Income Opportunities and Urban Employment in Ghana. J. Mod. Afr. Stud. 1973, 11, 61-89. [CrossRef]

17. De Soto, H. The Other Path: The Invisible Revolution in the Third World; Harper \& Row: New York, NY, USA, 1989.

18. Pratt, N. Informal Enterprise and Street Trading. In Contested Space: Street Trading, Public Space, and Livelihoods in Developing Cities; Brown, A., Ed.; ITDG: London, UK, 2006; pp. 37-53.

19. Maloney, W.F. Informality Revisited. World Dev. 2004, 32, 1159-1178. [CrossRef]

20. Dovey, K. Urban Design Thinking: A Conceptual Toolkit; Bloomsbury: New York, NY, USA, 2016.

21. Kamalipour, H.; Peimani, N. Assemblage Thinking and the City: Implications for Urban Studies. Curr. Urban Stud. 2015, 3, 402-408. [CrossRef]

22. Dovey, K. Informal urbanism and complex adaptive assemblage. Int. Dev. Plan. Rev. 2012, 34, 349-367. [CrossRef]

23. Bunnell, T.; Harris, A. Re-viewing informality: Perspectives from urban Asia. Int. Dev. Plan. Rev. 2012, 34, 339-348. [CrossRef]

24. Roy, A.; AlSayyad, N. (Eds.) Urban informality: Transnational perspectives from the Middle East, Latin America, and South Asia; Lexington: New York, NY, USA, 2004.

25. Neuwirth, R. Stealth of Nations: The global Rise of the Informal Economy; Anchor: New York, NY, USA, 2012.

26. Martínez, L.; Short, J.R.; Estrada, D. The urban informal economy: Street vendors in Cali, Colombia. Cities 2017, 66, 34-43. [CrossRef]

27. Xue, D.; Huang, G. Informality and the state's ambivalence in the regulation of street vending in transforming Guangzhou, China. Geoforum 2015, 62, 156-165. [CrossRef]

28. Recio, R.B.; Mateo-Babiano, I.; Roitman, S. Revisiting policy epistemologies on urban informality: Towards a post-dualist view. Cities 2017, 61, 136-143. [CrossRef]

29. De Certeau, M. The Practice of Everyday Life; University of California Press: Berkeley, CA, USA, 1984.

30. Bayat, A. Un-civil society: The politics of the "informal people". Third World Q. 1997, 18, 53-72. [CrossRef]

31. McFarlane, C. Rethinking Informality: Politics, Crisis, and the City. Plan. Theory Pract. 2012, 13, 89-108. [CrossRef]

32. Kamalipour, H. Forms of Informality and Adaptations in Informal Settlements. ArchNet Int. J. Archit. Res. 2016, 10, 60-75. [CrossRef]

33. Dovey, K.; Kamalipour, H. Informal/Formal Morphologies. In Mapping Urbanities: Morphologies, Flows, Possibilities; Dovey, K., Pafka, E., Ristic, M., Eds.; Routledge: New York, NY, USA, 2018; pp. 223-248. 
34. Kamalipour, H.; Dovey, K. Incremental Urbanisms. In Mapping Urbanities: Morphologies, Flows, Possibilities; Dovey, K., Pafka, E., Ristic, M., Eds.; Routledge: New York, NY, USA, 2018; pp. 249-267.

35. Dovey, K.; King, R. Forms of informality: Morphology and visibility of informal settlements. Built Environ. 2011, 37, 11-29. [CrossRef]

36. Lynch, K. Good City Form; MIT Press: Cambridge, MA, USA, 1981.

37. Sharit, K. Bhowmik Street Vendors in Asia: A Review. Econ. Political Wkly. 2005, 40, 2256-2264.

38. Brown, A. Challenging street livelihoods. In Contested Space: Street Trading, Public Space, and Livelihoods in Developing Cities; Brown, A., Ed.; ITDG: London, UK, 2006; pp. 3-16.

39. Taheri Tafti, M. Negotiating the order: The politics and policing of street vending in Tehran. Int. Dev. Plan. Rev. 2018, 41, 173-192. [CrossRef]

40. Wilson, T.D. Approaches to Understanding the Position of Women Workers in the Informal Sector. Lat. Am. Perspect. 1998, 25, 105-119. [CrossRef]

41. Peimani, N.; Dovey, K. Motorcycle mobilities. In Mapping Urbanities: Morphologies, Flows, Possibilities; Dovey, K., Pafka, E., Ristic, M., Eds.; Routledge: New York, NY, USA, 2018; pp. 119-128.

42. Maneepong, C.; Walsh, J.C. A new generation of Bangkok Street vendors: Economic crisis as opportunity and threat. Cities 2013, 34, 37-43. [CrossRef]

43. Yasmeen, G.; Nirathron, N. Vending in public space: The case of Bangkok. WIEGO Policy Brief Urban Policies 2014, 16, 1-18.

44. Agadjanian, V. Men Doing "Women's Work": Masculinity and Gender Relations among Street Vendors in Maputo, Mozambique. J. Men's Stud. 2002, 10, 329-342. [CrossRef]

45. Bromley, R. Organization, regulation and exploitation in the so-called 'urban informal sector': The street traders of Cali, Colombia. World Dev. 1978, 6, 1161-1171. [CrossRef]

46. Hanser, A. Street Politics: Street Vendors and Urban Governance in China. China Q. 2016, 226, $363-382$. [CrossRef]

47. Arámbulo, P.V., III; Almeida, C.R.; Cuéllar Solano, J.A.; Belotto, A.J. Street food vending in Latin America. Bull. Pan Am. Health Organ. 1994, 28, 344-354.

48. Setšabi, S.; Leduka, R.C. The Politics of Street Trading in Maseru, Lesotho. Urban Forum 2008, 19, $221-241$. [CrossRef]

49. Bell, J.S.; Loukaitou-Sideris, A. Sidewalk Informality: An Examination of Street Vending Regulation in China. Int. Plan. Stud. 2014, 19, 221-243. [CrossRef]

50. Peña, S. Informal Markets: Street Vendors in Mexico City. Habitat Int. 1999, 23, 363-372. [CrossRef]

51. Batréau, Q.; Bonnet, F. Managed Informality: Regulating Street Vendors in Bangkok. City Community 2016, 15, 29-43. [CrossRef]

52. Weng, C.Y.; Kim, A.M. The Critical Role of Street Vendor Organizations in Relocating Street Vendors into Public Markets. Cityscape 2016, 18, 47-70.

53. Hall, E.T. The Hidden Dimension; Doubleday: Garden City, NY, USA, 1966.

54. Dovey, K.; Polakit, K. Urban Slippage. In Loose Space: Possibility and Diversity in Urban Life; Franck, K., Stevens, Q., Eds.; Routledge: London, UK, 2007; pp. 113-131.

55. Gehl, J. Life between Buildings: Using Public Space; Van Nostrand Reinhold: New York, NY, USA, 1987.

56. Appleton, J. The Experience of Landscape; John Wiley: Chichester, UK, 1975.

57. Alexander, C.; Ishikawa, S.; Silverstein, M.; Jacobson, M.; Fiksdahl-King, I.; Angel, S. A Pattern Language: Towns, Buildings, Construction; Oxford University Press: New York, NY, USA, 1977.

58. Jacobs, J. The Death and Life of Great American Cities; Random House: New York, NY, USA, 1961.

59. Brown, A. Claiming the Streets: Property Rights and Legal Empowerment in the Urban Informal Economy. World Dev. 2015, 76, 238-248. [CrossRef]

60. Kamalipour, H.; Dovey, K. Mapping the visibility of informal settlements. Habitat Int. 2019, 85, 63-75. [CrossRef]

61. Hardin, G. The Tragedy of the Commons. Science 1968, 162, 1243-1248.

62. Bobić, M. Between the Edges: Street-building Transition as Urbanity Interface; Thoth Publishers: Bussum, The Netherlands, 2004.

63. Dovey, K.; Symons, F. Density without intensity and what to do about it: Reassembling public/private interfaces in Melbourne's Southbank hinterland. Aust. Plan. 2014, 51, 34-46. [CrossRef] 
64. Kamalipour, H. Mapping Urban Interfaces: A Typology of Public/Private Interfaces in Informal Settlements. Spaces Flows Int. J. Urban Extra Urban Stud. 2017, 8, 1-12. [CrossRef]

65. Dovey, K.; Wood, S. Public/private urban interfaces: Type, adaptation, assemblage. J. Urban. Int. Res. Placemaking Urban Sustain. 2015, 8, 1-16. [CrossRef]

66. Lyons, M.; Brown, A.; Li, Z. The 'third tier' of globalization. City 2008, 12, 196-206. [CrossRef]

(C) 2019 by the authors. Licensee MDPI, Basel, Switzerland. This article is an open access article distributed under the terms and conditions of the Creative Commons Attribution (CC BY) license (http://creativecommons.org/licenses/by/4.0/). 